\title{
Periods of Premodern Japanese History
}

\begin{tabular}{|c|c|c|c|}
\hline Jōmon & 縄文 & $\begin{array}{l}\text { To ninth or } \\
\text { sixth c. BCE } \\
\text { (scholarly } \\
\text { debate rages!) }\end{array}$ & $\begin{array}{l}\text { Hunting and gathering culture } \\
\text { leading to beginnings of } \\
\text { agriculture }\end{array}$ \\
\hline Yayoi & 弥生 & To $250 \mathrm{CE}$ & $\begin{array}{l}\text { Rice agriculture; small } \\
\text { chiefdoms }\end{array}$ \\
\hline $\begin{array}{l}\text { Tumulus } \\
\text { (Kofun) }\end{array}$ & 古墳 & $250-552$ & $\begin{array}{l}\text { Chiefdoms expand and } \\
\text { consolidate power; seeds of a } \\
\text { "realm" that came to occupy } \\
\text { much of the archipelago }\end{array}$ \\
\hline $\begin{array}{l}\text { Asuka- } \\
\text { Hakuhō }\end{array}$ & $\begin{array}{l}\text { 飛鳥- } \\
\text { 白鳳 }\end{array}$ & $552-710$ & $\begin{array}{l}\text { Early royal polities; expansion } \\
\text { of Buddhism as an officially } \\
\text { supported religion }\end{array}$ \\
\hline Nara & 奈良 & $710-794$ & $\begin{array}{l}\text { Throne consolidates power } \\
\text { through law codes and control } \\
\text { over the land }\end{array}$ \\
\hline Heian & 平安 & $794-1185$ & $\begin{array}{l}\text { First long-term capital established in } \\
\text { present Kyoto. By the tenth century } \\
\text { a courtier family, the Northern } \\
\text { Fujiwara, comes to dominate the } \\
\text { throne and government. }\end{array}$ \\
\hline (Insei) & (院政) & (c. 1100-1185) & $\begin{array}{l}\text { Retired sovereigns lead the } \\
\text { court, involving themselves in } \\
\text { accumulation and development of } \\
\text { estates. Warriors, especially the Ise } \\
\text { Taira, dominate the court at the } \\
\text { end of this period. }\end{array}$ \\
\hline Kamakura & 鎌倉 & $1185-1333$ & $\begin{array}{l}\text { After a civil war with the Ise } \\
\text { Taira, victorious Minamoto forces } \\
\text { establish a military government } \\
\text { (shogunate) in Kamakura; at first } \\
\text { the shogunate shares power with } \\
\text { the throne and court, and then it } \\
\text { becomes dominant. }\end{array}$ \\
\hline
\end{tabular}




\begin{tabular}{|c|c|c|c|}
\hline $\begin{array}{l}\text { Kenmu } \\
\text { Restoration }\end{array}$ & $\begin{array}{l}\text { 建武新 } \\
\text { 政 }\end{array}$ & 1334-1336 & $\begin{array}{l}\text { Go-Daigo Tennō attempts to } \\
\text { restore the power of the throne }\end{array}$ \\
\hline $\begin{array}{l}\text { Nanbokuchō } \\
\text { (Northern } \\
\text { and Southern } \\
\text { Courts) }\end{array}$ & 南北朝 & 1336-1392 & $\begin{array}{l}\text { Civil war between supporters } \\
\text { of two courts: the northern } \\
\text { court in Kyoto supported by } \\
\text { the new Ashikaga shogunate, } \\
\text { and Go-Daigo's court-in-exile at } \\
\text { Yoshino }\end{array}$ \\
\hline $\begin{array}{l}\text { Muromachi/ } \\
\text { Ashikaga }\end{array}$ & $\begin{array}{l}\text { 室町/ } \\
\text { 足利 }\end{array}$ & 1392-1568 & $\begin{array}{l}\text { Power is consolidated under } \\
\text { the Ashikaga shogunate and } \\
\text { provincial overlords (shugo) }\end{array}$ \\
\hline (Sengoku) & (戦国) & $(1467-1568)$ & $\begin{array}{l}\text { Civil wars. Warlords (daimyō) } \\
\text { control territories and vie to } \\
\text { expand them. }\end{array}$ \\
\hline $\begin{array}{l}\text { Azuchi- } \\
\text { Momoyama }\end{array}$ & $\begin{array}{l}\text { 安土桃 } \\
\text { 山 }\end{array}$ & $1568-1603$ & $\begin{array}{l}\text { Civil wars come to an end under } \\
\text { three successive unifying generals }\end{array}$ \\
\hline $\begin{array}{l}\text { Edo/ } \\
\text { Tokugawa }\end{array}$ & $\begin{array}{l}\text { 江戸/ } \\
\text { 徳川 }\end{array}$ & $1603-1867$ & $\begin{array}{l}\text { The final unifier, Tokugawa } \\
\text { Ieyasu, establishes a shogunate } \\
\text { in Edo (modern Tokyo). Japan } \\
\text { enters its early modern age. }\end{array}$ \\
\hline
\end{tabular}

